\title{
Pengaruh Umur Tanaman dan Posisi Pelepah terhadap Komponen Kimia Tanaman Kelapa Sawit (Elaeis Guineensis)
}

\author{
Kamaliah \\ Dosen Program Studi Teknik Lingkungan Universitas Muhammadiyah Palangkaraya
}

\begin{abstract}
ABSTRAK
Kelapa sawit merupakan bahan baku alternatif yang dapat menggantikan atau paling tidak dapat menjadi bahan baku penunjang produksi pulp dan kertas, yang dapat diperoleh dalam waktu yang lebih singkat dan lebih mudah didapat dalam skala yang besar. Tujuan penelitian ini adalah untuk mengkaji pengaruh umur tanaman dan posisi pelepah kelapa sawit terhadap komponen kimia. Penelitian ini dilakukan dengan menggunakan Rancangan Acak Lengkap Faktorial (RAL Faktorial). Faktor pertama adalah umur tanaman kelapa sawit yang terdiri atas 3 taraf yaitu umur 3 tahun (a1), 5 tahun (a2), dan 7 tahun (a3). Sedangkan faktor kedua adalah posisi pelepah kelapa sawit yang terdiri atas 3 taraf yaitu pelepah muda (b1), pelepah sedang (b2), dan pelepah tua (b3). Ulangan dilakukan sebanyak 4 kali. Berdasarkan komponen kimia selulosa secara keseluruhan dari ketiga posisi pelepah kelapa sawit memiliki selulosa tinggi dengan kisaran (43-47 $\%$ ), dan berada diatas kategori kayu daun lebar yang memiliki selulosa berkisar 40-45 \%, sehingga baik apabila digunakan sebagai bahan baku pulp dan kertas.
\end{abstract}

Kata kunci: pelepah, kelapa sawit, komponen kimia

\section{PENDAHULUAN}

Hutan merupakan salah satu sumber daya alam yang memiliki banyak kekayaan dan sebagian besar wilayah Indonesia dilindungi oleh hutan. Hasil hutan yang diperoleh bukan hanya meliputi kayu, tetapi juga meliputi kekayaan alam lainnya yang disebut dengan hasil hutan bukan kayu yang meliputi tanaman tak berkayu, resin, bahan karet, minyak atsiri, minyak lemak, ekowisata, tanaman obat, dan lain-lain.

Indonesia memiliki kawasan hutan yang sangat besar di seluruh kawasan Asia Tenggara. Indonesia juga terkenal dengan kekayaan hutannya baik berupa kayu maupun non kayu. Seiring dengan kemajuan teknologi dan lajunya pertumbuhan penduduk maka kebutuhan akan kayu sebagai bahan baku untuk kebutuhan rumah tangga dan perkantoran seperti kertas semakin meningkat.
Kebutuhan bahan baku kayu dalam lima tahun terakhir untuk industri olahan kayu, salah satunya untuk bahan baku pulp dan kertas secara perlahan meningkat, sementara kayu-kayu semakin sulit diperoleh. Hak pengusahaan hutan (HPH) skala kecil yang dikeluarkan oleh pemerintah daerah telah mencapai belasan ribu HPH di seluruh Indonesia tidak pernah mencukupi kebutuhan kayu nasional. Pabrik-pabrik kertas belum berhasil membangun hutan-hutan tanaman dan beberapa diantaranya terancam tutup karena tidak mampu menutupi kebutuhan bahan baku. (Wahana Lingkungan Hidup Indonesia, 2008). Berkaitan dengan keadaan di atas, maka pemanfaatan bahan baku berupa non kayu semakin meningkat, salah satu alternatif adalah kelapa sawit.

Kelapa sawit merupakan bahan baku alternatif yang dapat menggantikan atau paling tidak dapat menjadi bahan baku penunjang produksi pulp dan kertas, diperoleh 
dalam waktu yang lebih singkat, juga lebih mudah didapat dalam skala yang besar. Kelapa sawit termasuk definisi pohon yang tingginya dapat mencapai $24 \mathrm{~m}$ dengan umur tumbuhan 25 tahun sampai 30 tahun (Sunarko, 2007). Bunga dan buahnya berupa tandan, serta bercabang banyak. Buahnya kecil dan apabila masak, berwarna merahkehitaman. Pemanfaatan kelapa sawit dapat dilakukan secara maksimal antara lain untuk minyak sawit mentah crude palm oil (CPO), biomassa, dan bahan makanan.

Menanggapi hal tersebut, peneliti tertarik mengembangkan pemanfaatan pelepah kelapa sawit sebagai bahan penganti kayu untuk pulp dan kertas, sehingga diperlukan penelitian tentang komponen kimia pelepah kelapa sawit, agar memungkinkan ditindaklanjuti guna menanggulangi masalah kekurangan pasokan bahan baku pulp dan kertas yang terjadi selama ini. Penelitian ini bertujuan mengkaji (1) pengaruh umur tanaman dan posisi pelepah terhadap dimensi serat pada pelepah kelapa sawit, (2) pengaruh umur tanaman dan posisi pelepah terhadap komponen kimia pada pelepah kelapa sawit dan (3) nilai turunan untuk pelepah kelapa sawit.

\section{METODE PENELITIAN}

\begin{tabular}{llrr}
\multicolumn{1}{c}{ Penelitian } & ini dilaksanakan di \\
Laboratorium & Terpadu & Universitas \\
Muhammadiyah & \multicolumn{2}{c}{ Palangkaraya } & dan \\
Laboratorium & Teknologi & Hasil & Hutan \\
Universitas Palangkaraya selama & 6 & bulan \\
mulai Agustus 2012 & sampai Januari 2013 .
\end{tabular}

\section{Bahan Penelitian}

Bahan yang digunakan adalah pelepah kelapa sawit dari PT. Surya Sawit Sejati Km. 20 Pangkalan Bun Kabupaten Kotawaringin Barat, asam asetat glacial $\left(\mathrm{CH}_{3} \mathrm{COOH}\right) 65 \%$ dan hidrogen peroksida $\left(\mathrm{H}_{2} \mathrm{O}_{2}\right) 30 \%$. aquades, $\mathrm{NaOH}, \mathrm{NaClO}_{2}$, ethanol $70 \%$, benzen, safranin, kertas lakmus, label, aquades, serta kertas saring.

Peralatan yang digunakan untuk penelitian ini adalah tabung reaksi, kompor gas, corong kaca, mikroskop CETI model 3100-5000-triton II, lensa okuler Pembesaran
$10 \mathrm{x}$ dan lensa okuler $40 \mathrm{x}$, tabung klise Photo, cover glass dan object glass, pengaduk kaca, kamera, pisau potong/gergaji, pita ukur/meteran, gelas ukur, gelas piala, oven, desikator, cawan, hot plate, tabel rekapitulasi data, dan pipet tetes.

\section{Prosedur Penelitian \\ Pengujian contoh uji}

Tumbuhan kelapa sawit yang dipilih dalam bentuk lurus, tidak bengkok, dan tidak cacat atau dalam keadaan sehat dan pelepah kelapa sawit yang diambil berumur 3 tahun, 5 tahun dan 7 tahun.

\section{Metode Penelitian}

Penelitian ini dilakukan dengan menggunakan Rancangan Acak Lengkap Faktorial (RAL Faktorial). Faktor pertama adalah umur tanaman kelapa sawit yang terdiri atas 3 taraf yaitu umur 3 tahun (a1), 5 tahun (a2), dan 7 tahun (a3). Sedangkan faktor kedua adalah posisi pelepah kelapa sawit yang terdiri atas 3 taraf yaitu pelepah muda (b1), pelepah sedang (b2), dan pelepah tua (b3). Ulangan dilakukan sebanyak 4 kali, sehingga seluruh sampel yang digunakan adalah $3 \times 3 \times 4=36$ buah. Khusus sampel dimensi serat diambil setiap 1 ulangan 20 serat sesuai dengan metode yang dipakai IAWA (1989).

Komponen Kimia yang diteliti yaitu (1) kadar air, (2) zat ekstraktif kelarutan dalam air dingin, (3) zat ekstraktif kelarutan dalam air panas, (4) zat ekstraktif kelarutan dalam $\mathrm{NaOH}$, (5) zat ekstraktif kelarutan dalam alkohol dan benzen, (6) kadar abu, (7) lignin, (8) holoselulosa, (9) selulosa dan (10) hemi selulosa.

\section{Analisis Data}

Sebelum dilakukan uji F, data diuji kehomogenannya untuk mendapatkan keseragaman menggunakan uji Barlett dan tabel Analisis Sidik Varian. 
HASIL DAN PEMBAHASAN

\section{Komponen Kimia}

\section{Kelarutan dalam Air Dingin}

Hasil rata-rata kelarutan dalam air dingin pelepah kelapa sawit yang umur 3 tahun (8.08\%), 5 tahun (5.96\%), dan 7 tahun (5.77 \%). Berdasarkan Depertemen Pertanian dan Dirjen Kehutanan (1976), kelarutan dalam air dingin rata-rata keseluruhan pelepah kelapa sawit termasuk dalam daun lebar sebesar (6.60\%) dengan kisaran 1-12\%. Berdasarkan sidik ragam umur tanaman dan posisi pelepah tidak berpengaruh nyata terhadap kelarutan dalam air dingin pelepah kelapa sawit pada umur 3 tahun, 5 tahun, dan 7 tahun. Adanya perubahan nilai rata-rata kelarutan dalam air dingin pada umur 3 tahun bila dibandingkan dengan umur 5 tahun dan 7 tahun. Hal ini diduga umur tanaman dan posisi pelepah kelapa sawit cenderung memiliki kandungan kelarutan zat ektraktifnya tinggi karena pada bagian tersebut sudah tidak mengalami masa pertumbuhan lagi serta adanya faktor-faktor yang menghabat zat ekstraktif dan juga disebabkan oleh tempat tumbuh yang berbeda. Komponen ektraksi pada kelarutan dalam air dingin hasil yang didapat adalah tanin, gum, dan bahan pewarna kayu Panshin dan de Zeeuw (1980).

\section{Kelarutan Dalam Air Panas}

Hasil rata-rata kelarutan dalam air panas pelepah kelapa sawit yang umur 3 tahun $(9.15$ $\%), 5$ tahun $(5.53 \%)$, dan 7 tahun $(3.50 \%)$. Berdasarkan Depertemen Pertanian dan Dirjen Kehutanan (1976), kelarutan dalam air panas rata - rata keseluruhan pelepah kelapa sawit termasuk dalam daun lebar sebesar $(6.06 \%)$ dengan kisaran 1-12\%.

Tabel 1. Rata-rata kelarutan dalam air panas

\begin{tabular}{ccccc}
\hline \multirow{2}{*}{$\begin{array}{c}\text { Umur } \\
\text { (tahun) }\end{array}$} & \multicolumn{4}{c}{ Posisi } \\
\cline { 2 - 5 } & Tua & Sedang & Muda & Rata-rata \\
\hline 3 & 9.04 & 9.35 & 9.04 & $9.14^{\mathrm{b}}$ \\
5 & 5.08 & 5.52 & 5.52 & $5.37^{\mathrm{a}}$ \\
7 & 3.28 & 5.98 & 5.98 & $5.08^{\mathrm{a}}$ \\
& \multicolumn{3}{c}{ BNT 5\% $=2.03$}
\end{tabular}

Keterangan: Angka-angka yang diikuti dengan huruf yang sama pada setiap kolom yang sama tidak berbeda nyata pada uji BNT 5\%= 2.03
Berdasarkan sidik ragam efek interaksi antara umur tanaman dan posisi pelepah tidak teruji nyata. Kelarutan dalam air panas hanya dipengaruhi oleh umur tanaman 3 tahun. Kelarutan dalam air panas yang paling tinggi diperoleh pada pelepah sedang, yaitu 9.35\% (Tabel 1). Adanya perubahan nilai rata-rata kelarutan dalam air panas pada umur 3 tahun bila dibandingkan dengan umur 5 tahun dan 7 tahun. Hal ini diduga adanya perbedaan pada penyebaran kandungan ekstraktif dalam beberapa jenis tanaman pelepah kelapa sawit dan tempat tumbuh yang berbeda. Adapun menurut Fengel dan Wegener (1995) menyatakan bahwa kandungan dan komposisi ektraktif berubah di antara spesies kayu, tetapi juga terhadap variasi yang tergantung pada tapak geografi dan musim.

\section{Kelarutan dalam $\mathrm{NaOH}$}

Hasil rata-rata kelarutan dalam $\mathrm{NaOH}$ pelepah kelapa sawit yang umur 3 tahun (4.76\%), 5 tahun (5.53\%), dan 7 tahun (3.64 $\%)$. Berdasarkan Depertemen Pertanian dan Dirjen Kehutanan (1976), kelarutan dalam air $\mathrm{NaOH}$ rata - rata keseluruhan pelepah kelapa sawit termasuk dalam daun lebar sebesar (4.64\%) dengan kisaran 1-12\%.

Tabel 2. Rata-Rata Kelarutan dalam $\mathrm{NaOH}$

\begin{tabular}{ccccc}
\hline \multirow{2}{*}{$\begin{array}{c}\text { Umur } \\
\text { (tahun) }\end{array}$} & \multicolumn{4}{c}{ Posisi } \\
\cline { 2 - 5 } & Tua & Sedang & Muda & Rata-rata \\
\hline 3 & 5.07 & 4.11 & 5.10 & $4.76^{\mathrm{a}}$ \\
5 & 5.08 & 5.52 & 5.98 & $5.53^{\mathrm{b}}$ \\
7 & 3.64 & 3.80 & 3.47 & $3.64^{\mathrm{a}}$ \\
& \multicolumn{3}{c}{ BNT 5\% $=1.29$}
\end{tabular}

Keterangan: Angka-angka yang diikuti dengan huruf yang sama pada setiap kolom yang sama tidak berbeda nyata pada uji BNJ $5 \%=1.29$

Berdasarkan sidik ragam efek interaksi antara umur tanaman dan posisi pelepah tidak teruji nyata. Kelarutan dalam $\mathrm{NaOH}$ hanya dipengaruhi oleh umur tanaman 5 tahun. Kelarutan dalam $\mathrm{NaOH}$ yang paling tinggi diperoleh pada pelepah muda, yaitu $5.98 \%$ (Tabel 2). Hal ini diduga adanya faktor faktor penghambat yang mempengaruhi kandungan ekstraktif yaitu pengaruh tempat tumbuh, iklim, dan kondisi tanah. 


\section{Kelarutan dalam Alkohol dan Benzen}

Hasil rata-rata kelarutan dalam alkohol dan benzen pelepah kelapa sawit yang umur 3 tahun (10.79\%), 5 tahun (10.88\%), dan 7 tahun (12.64 \%). Berdasarkan Depertemen Pertanian dan Dirjen Kehutanan (1976), kelarutan dalam alkohol dan benzen rata rata keseluruhan pelepah kelapa sawit termasuk dalam daun lebar sebesar (11.44\%) dengan kisaran 1-12\%.

Tabel 3. Rata-Rata Kelarutan dalam Alkohol

\begin{tabular}{cccc}
\multicolumn{4}{c}{ dan Benzen } \\
\hline Umur & \multicolumn{3}{c}{ Posisi } \\
\cline { 2 - 4 } (tahun) & Tua & Sedang & Muda \\
\hline \multirow{2}{*}{3} & $11.02^{\mathrm{a}}$ & $10.62^{\mathrm{a}}$ & $10.55^{\mathrm{a}}$ \\
& $\mathrm{A}^{\mathrm{A}}$ & $\mathrm{A}^{\mathrm{a}}$ & \\
5 & $12.56^{\mathrm{a}}$ & $11.84^{\mathrm{a}}$ & $8.23^{\mathrm{a}}$ \\
& $\mathrm{B}^{\mathrm{A}}$ & $\mathrm{A}^{\mathrm{a}}$ & $\mathrm{A}$ \\
7 & $11.61^{\mathrm{a}}$ & $11.27^{\mathrm{a}}$ & $15.01^{\mathrm{b}}$ \\
& $\mathrm{A}$ & $\mathrm{A}$ & $\mathrm{B}$
\end{tabular}

BNT $5 \%=2.91$

Keterangan: Angka-angka yang diikuti dengan hurup kecil yang sama pada setiap kolom dan hurup kapital yang sama serta setiap baris tidak berbeda nyata pada uji BNT $5 \%=2.91$

Sidik ragam efek interaksi antara umur tanaman dan posisi pelepah kelapa sawit berpengaruh nyata terhadap kelarutan dalam alkohol dan benzen, yang terbesar diperoleh pada umur tanaman 7 tahun dan posisi pelepah muda dengan nilai $15.01 \%$ (Tabel 3). Hal ini diduga kandungan kelarutan zat ektraktifnya tinggi karena pada bagian tersebut sudah tidak mengalami masa pertumbuhan lagi. Menurut Brown et al (1949), zat-zat ektraktif merupakan komponen ekstraktif dari kayu dengan dieifinisikan sebagai substansi yang dapat dipisahkan dari kayu dengan cara ekstraksi menggunakan pelarut-pelarut netral seperti air, aseton, alkohol, benzene, eter, dan klorofom atau valabilisasi memakai uap air.

\section{Kadar Abu}

Hasil rata-rata kadar abu pelepah kelapa sawit yang umur 3 tahun (1.74 \%), 5 tahun $(2.35 \%)$ dan 7 tahun (2.12\%). Berdasarkan Depertemen Pertanian dan Dirjen Kehutanan (1976), kadar abu keseluruhan pelepah kelapa sawit termasuk dalam daun lebar sebesar (2.07\%) dengan kisaran 0.10 - 6\%.

Tabel 4. Rata-Rata Kadar Abu

\begin{tabular}{|c|c|c|c|}
\hline \multirow{2}{*}{$\begin{array}{l}\text { Umur } \\
\text { (tahun) }\end{array}$} & \multicolumn{3}{|c|}{ Posisi } \\
\hline & Tua & Sedang & Muda \\
\hline 3 & $\begin{array}{c}1.14^{\mathrm{a}} \\
\mathrm{A}\end{array}$ & $1.93^{a}$ & $2.15^{\mathrm{a}}$ \\
\hline 5 & $\underset{A}{2.32^{b}}$ & $\underset{\mathrm{A}}{2.26^{\mathrm{b}}}$ & $\underset{A}{2.47^{a}}$ \\
\hline 7 & $\underset{\mathrm{A}}{2.25^{\mathrm{a}}}$ & ${ }_{\mathrm{A}}^{1.27^{\mathrm{a}}}$ & $\underset{B}{2.82^{b}}$ \\
\hline & BNT : & $b=0.46$ & \\
\hline
\end{tabular}

Keterangan: Angka-angka yang diikuti dengan hurup kecil yang sama pada setiap kolom dan hurup kapital yang sama serta setiap baris tidak berbeda nyata pada uji BNJ $5 \%=0.46$

Berdasarkan sidik ragam efek interaksi antara umur tanaman dan posisi pelepah kelapa sawit berpengaruh nyata terhadap kadar abu. Kadar abu terbesar diperoleh pada kombinasi perlakuan umur tanaman 7 tahun dengan posisi pelepah muda dengan nilai 2.82 $\%$ (Tabel 4). Hal ini diduga posisi pelepah kelapa sawit bagian tua, sedang dan muda terjadi penumpukan anorganik sehingga komponen anorganik yang paling tinggi adalah bagian muda, yang dipengaruhi oleh lamanya penyimpanan sehingga dipengaruhi oleh cahaya, iklim dan tempat penyimpanan. Karena unsur-unsur anorganik dalam kayu berbeda untuk berbagai jenis kayu (Mahali, 1999). Pansin dan de Zeeuw (1980) menjelaskan bahwa panjang serat akan bertambah seiring dengan bertambahnya tinggi pada pohon sampai mencapai batas maksimum pada ketinggian tertentu, untuk itulah posisi bagian ujung presentase kandungan abu yang relative lebih besar.

\section{Lignin}

Hasil rata-rata lignin pelepah kelapa sawit yang umur 3 tahun (31.27\%), 5 tahun $(33.25 \%)$ dan 7 tahun $(32.16 \%)$. Berdasarkan Depertemen Pertanian dan Dirjen Kehutanan (1976), rata - rata lignin keseluruhan pelepah kelapa sawit termasuk dalam daun lebar sebesar (32.23\%) dengan kisaran 18-33\%. 
Tabel 5. Rata-Rata Lignin

\begin{tabular}{ccccc}
\hline Umur & \multicolumn{4}{c}{ Posisi } \\
\cline { 2 - 5 } (tahun) & Tua & Sedang & Muda & Rata-rata \\
\hline 3 & 33.13 & 30.33 & 30.34 & $31.27^{\mathrm{a}}$ \\
5 & 33.22 & 32.35 & 34.16 & $33.24^{\mathrm{b}}$ \\
7 & 33.29 & 31.86 & 31.33 & $32.16^{\mathrm{a}}$ \\
Rata- & 33.21 & $\begin{array}{c}31.51 \\
\text { rata }\end{array}$ & $\begin{array}{c}\text { B } \\
\text { ra }\end{array}$ & A \\
\end{tabular}

Keterangan : Angka-angka yang diikuti dengan hurup kecil yang sama pada kolom yang sama dan hurup kapital yang sama pada baris yang sama tidak berbeda nyata pada uji BNJ $5 \%=2.34$

Berdasarkan sidik ragam efek interaksi antara umur tanaman dan posisi pelepah tidak teruji nyata. Lignin hanya dipengaruhi oleh umur tanaman 5 tahun dan posisi pelepah. Lignin yang paling tinggi diperoleh pada pelepah muda, yaitu 34.16\% (Tabel 5). Hal ini diduga oleh perubahan-perubahan yang terjadi pada arah pelepah yang tidak begitu jelas, dan adanya kenaikan sedikit dalam kadar lignin serta dipengaruhi juga oleh tempat tumbuh, iklim dan letak pada pelepah kelapa sawit. Menurut Soenardi, (1976) menyatakan bahwa terjadinya struktur dan reaksi-reaksi lignin belum seluruhnya yang dihasilkan dari strukur-struktur molekulnya dan terdapat di dalam dinding serat, maka isolasi lignin dalam bentuk yang tidak berubah dan penentuannya secara pasti hingga sekarang sebelum dimungkinkan. Lignin merupakan polimer dari unit-unit fenilpropana. Lignin adalah komponen dinding serat yang berbeda dari selulosa dan hemiselulosa karena lignin bukan suatu karbohidrat, melainkan suatu senyawa aromatik.

\section{Holoselulosa}

Hasil rata-rata holoselulosa pelepah kelapa sawit yang umur 3 tahun $\%), 5$ tahun $(75.40 \%)$, dan 7 tahun $(77.13 \%)$. Berdasarkan Depertemen Pertanian dan Dirjen Kehutanan (1976), rata-rata holoselulosa keseluruhan pelepah kelapa sawit termasuk dalam daun lebar sebesar (76.42\%).
Tabel 6. Rata-Rata Holoselulosa

\begin{tabular}{|c|c|c|c|}
\hline \multirow{2}{*}{$\begin{array}{l}\text { Umur } \\
\text { (tahun) }\end{array}$} & \multicolumn{3}{|c|}{ Posisi } \\
\hline & Tua & Sedang & Muda \\
\hline 3 & $\underset{B}{78.98^{b}}$ & $\underset{\mathrm{A}}{75.31^{\mathrm{a}}}$ & $\underset{\mathrm{A}}{75.91^{\mathrm{a}}}$ \\
\hline 5 & $\underset{B}{76.12^{a}}$ & $\underset{A}{75.80^{a}}$ & $\underset{A}{74.27^{a}}$ \\
\hline 7 & $\begin{array}{c}77.08^{\mathrm{a}} \\
\mathrm{A}\end{array}$ & $77.29^{b}$ & $77.01^{b}$ \\
\hline
\end{tabular}

BNT $5 \%=1.46$

Keterangan: Angka-angka yang diikuti dengan hurup kecil yang sama pada setiap kolom dan hurup kapital yang sama serta setiap baris tidak berbeda nyata pada uji BNJ $5 \%=1.46$

Berdasarkan sidik ragam efek interaksi antara umur tanaman dan posisi pelepah berpengaruh nyata terhadap holoselulosa. Holoselulosa terbesar diperoleh pada kombinasi perlakuan umur tanaman 3 tahun dengan posisi pelepah tua dengan nilai $78.98 \%$. Hal ini diduga karena struktur pelepah yang heterogen sehingga kandungan dan komposisi konstituennya termasuk polisakarida. Pertumbuhan dinding serat yang mana mengalami pertumbuhan sebagian besar berisi selulosa. Holoselulosa adalah gabungan dari selulosa dengan hemiselulosa,untuk mendeterimanasi holoselulosa digunakan cara oksidasi, sedangkan hemiselulosa merupakan senyawa antara dalam biosintetis selulosa. Hemiselulosa berfungsi sebagai bahan pendukung dalam dinding-dinding serat. Hemiselulosa terdiri dari pentose, heksosan dan sedikit asam (Sjostrom, 1995).

\section{Selulosa}

Hasil rata-rata selulosa pelepah kelapa sawit yang umur 3 tahun (46.01\%), 5 tahun $(46.16 \%)$, dan 7 tahun $(44.86 \%)$. Berdasarkan Depertemen Pertanian dan Dirjen Kehutanan (1976), rata - rata selulosa keseluruhan pelepah kelapa sawit termasuk dalam daun lebar sebesar $(45.68 \%)$ berada pada kisaran 40 - $45 \%$.

Berdasarkan sidik ragam efek interaksi antara umur tanaman dan posisi pelepah berpengaruh nyata terhadap selulosa. Selulosa terbesar diperoleh pada kombinasi perlakuan umur tanaman 3 tahun dan 5 tahun dengan posisi pelepah tua ataupun sedang dengan 
nilai 47.49\%-47.21\% (Tabel 7). Hal ini diduga bagian pangkal mempunyai tingkat kerapatan lebih tinggi dibandingkan bagian tengah dan ujung.

Tabel 7. Rata-Rata Selulosa

\begin{tabular}{|c|c|c|c|}
\hline \multirow{2}{*}{$\begin{array}{l}\text { Umur } \\
\text { (tahun) }\end{array}$} & \multicolumn{3}{|c|}{ Posisi } \\
\hline & Tua & Sedang & Muda \\
\hline 3 & $\underset{B}{47.49^{b}}$ & $\underset{A}{44.67^{a}}$ & $\underset{A}{45.86^{a}}$ \\
\hline 5 & $\begin{array}{c}46.41^{\mathrm{a}} \\
\mathrm{A}\end{array}$ & $47.21^{b}$ & $\begin{array}{c}44.87^{\mathrm{a}} \\
\mathrm{A}\end{array}$ \\
\hline 7 & $\underset{A}{43.72^{a}}$ & $\begin{array}{c}44.55^{\mathrm{a}} \\
\mathrm{A}\end{array}$ & $\underset{B}{46.31^{a}}$ \\
\hline & BNT & $b=1.78$ & \\
\hline
\end{tabular}

Keterangan : Angka-angka yang diikuti dengan hurup kecil yang sama pada setiap kolom dan hurup kapital yang sama serta setiap baris tidak berbeda nyata pada uji BNJ $5 \%=1.78$

Selulosa merupakan konstituen utama kayu karena 40-45\% bahan kering dalam kayu adalah selulosa, terutama terdapat dalam dinding serat sekunder. Selulosa adalah homopolisakarida yang tersusun atas unit-unit $\beta$-D-glukopiranosa yang terikat satu sama lain dengan ikatan glikosida. Selulosa merupakan dasar pulp, kertas dan pembuatan derivate selulosa seperti selulosa, selulosa asetat, selulosa alkali, etil selulosa dan sebagainya Panshin dan De Zeeuw (1980) menyatakan bahwa panjang serat bertambah dengan bertambahnya tinggi batang hingga mencapai ketinggian tertentu. Menurut Scarai-Rad (1990), bila berhubungan dengan letak kayu dalam batang, kerapatan terendah terdapat pada posisi bagian atas, mengandung kayu dengan kerapatan tinggi pada posisi terbawah, sehingga rendahmya kerapatan bagian ujung dapat ditunjukkan bahwa pada bagian tersebut umumnya disusun dengan sel-sel dengan dinding yang tipis, dimana belum mengalami proses penebalan primer (lignifikasi).

\section{Hemiselulosa}

Hasil rata-rata hemiselulosa pelepah kelapa sawit yang umur 3 tahun $(30.73 \%), 5$ tahun (29.07\%), dan 7 tahun (32.27\%). Berdasarkan Depertemen Pertanian dan Dirjen Kehutanan (1976), rata - rata hemiselulosa keseluruhan pelepah kelapa sawit termasuk dalam daun lebar sebesar (30.69\%) dengan kisaran $21-24 \%$.

Tabel 8. Rata-Rata Hemiselulosa

\begin{tabular}{|c|c|c|c|c|}
\hline \multirow{2}{*}{$\begin{array}{l}\text { Umur } \\
\text { (tahun) }\end{array}$} & \multicolumn{4}{|c|}{ Posisi } \\
\hline & Tua & Sedang & Muda & Rata-rata \\
\hline 3 & 31.48 & 30.64 & 30.05 & $30.72^{\mathrm{a}}$ \\
\hline 5 & 29.71 & 28.09 & 29.40 & $29.07^{\mathrm{a}}$ \\
\hline 7 & 33.36 & 32.74 & 30.70 & $32.27^{\mathrm{b}}$ \\
\hline \multicolumn{5}{|c|}{$\mathrm{BNT} 5 \%=2.03$} \\
\hline
\end{tabular}

Berdasarkan sidik ragam efek interaksi antara umur tanaman dan posisi pelepah tidak teruji nyata. Hemiselulosa hanya dipengaruhi oleh umur tanaman 7 tahun. Hemiselulosa yang paling tinggi diperoleh pada pelepah tua, yaitu $33.36 \%$. Hal ini diduga adanya faktorfaktor yang variasi susunan kandungan kimia kayu yang dipengaruhi oleh keadaan tempat tumbuh, jenis tanah serta iklim. Hemiselulosa merupakan pengurangan dari hasil analisi kandungan holoselulosa dengan hasil analisis kandungan selulosa, dan ini salah satu dari indikator penentuaan tinggi atau rendah nilai kandungan selulosa suatu jenis kayu memenuhi syarat, baik sebagai bahan baku pulp dan kertas Panshin dan de Zeeuw (1980).

\section{Pemanfaatan Kualitas Pelepah Kelapa Sawit}

Pemanfaatan kualitas pelepah kelapa sawit disesuaikan pada sifat anatomi dan komoponen kimia dengan penggunaan kualitas pemakaian akhirnya. Nilai rataan krakteristik komponen kimia (\%) pelepah kelapa sawit disajikan pada Tabel 9.

Tabel 9. Nilai Rataan Krakteristik Komponen Kimia (\%) Pelepah Kelapa Sawit

\begin{tabular}{llrrr}
\hline \multirow{2}{*}{ Parameter Nilai/Kelas } & \multicolumn{3}{c}{$\begin{array}{c}\text { Umur Pelepah Kelapa Sawit } \\
\text { (tahun) }\end{array}$} \\
\cline { 3 - 5 } & & \multicolumn{1}{c}{5} & \multicolumn{1}{c}{7} \\
\hline \multirow{2}{*}{ Ekstraktif } & Air Dingin & 8.08 & 5.96 & 5.77 \\
Kelarutan & Air Panas & 9.15 & 5.53 & 3.50 \\
& NaOH & 4.76 & 5.53 & 3.64 \\
Kadar Abu & Alben & 10.76 & 10.88 & 12.64 \\
Lignin & 1.74 & 2.35 & 2.12 \\
Holoselulosa & 31.27 & 33.25 & 32.16 \\
Selulosa & 76.73 & 75.40 & 77.13 \\
Hemiselulosa & 46.01 & 46.16 & 44.86 \\
\hline
\end{tabular}


Kesesuaian umur tanaman dengan posisi pelepah sebagai bahan baku pulp dan kertas dinilai dari segi nilai turunan dimensi serat dan kandungan selulosa, lignin dan zat ekstraktif. Hasil keseluruhan dari penelitian ini menyatakan bahwa umur 7 tahun dengan posisi pelepah bagian tua dan muda yang dominan untuk bahan baku pulp dan kertas. Adapun selain data yang diperoleh dari laboratorium, ada juga data pendukung yang diperoleh dari hasil wawancara dengan pihak yang relevan untuk penelitian ini.

\section{KESIMPULAN}

Berdasarkan berbagai variabel komponen kimia yang berperan dalam menentukan kualitas pulp dan kertas, maka kelapa sawit yang berumur 7 tahun dengan posisi pelepah muda dan tua dapat dijadikan bahan baku pengganti kayu untuk pulp dan kertas. Komponen kimia selulosa secara keseluruhan dari ketiga posisi pelepah kelapa sawit memiliki selulosa tinggi dengan kisaran (43-47 \%), dan berada diatas kategori kayu daun lebar yang memiliki selulosa berkisar 40-45\%, sehingga baik apabila digunakan sebagai bahan baku pulp dan kertas.

\section{DAFTAR PUSTAKA}

Brown, H.P.,A.J. Panshin dan C.C. Forsaith. 1949, Texbook of Wood Technology. Volume I. McBraw-Hill Book Company, New York, Toronto London.
Departemen Kehutanan dan Perkebunan. 1999. Panduan Kehutanan Indonesia. Cetakan kedua. Koperasi Karyawan Departemen Kehutanan dan Perkebunan RI. Jakarta.

Departemen Hutan, 1999. Kelapa Sawit. Penebar Swadaya. Jakarta.

Direktorat Jenderal Kehutanan 1976. Vedemecum Kehutanan Indonesia. Dirjen Kehutanan Jakarta.

Fengel, D. dan G. Wegener, 1995, KAYU: Kimia, Ultrastruktur, Reaksi-reaksi. Edisi Kedua, Diterjemahkan oleh Hardjono Sastrohamidjojo, Gadjah Mada University Press, Yogyakarta.

Mahali, 1999, Analisis Komposisi Kimia Kayu Rawa Gambut dari Jenis Tumeh (Combretocarpus rotundatus Danser) dan Terentang (Campnosperma auriculatum Blume) Berdasarkan Letak Kayu Dalam Batang, Tesis, Program Pascasarjana Universitas Mulawarman, Samarinda.

Panshin, A. J. dan Carl De Zeeuw., 1980. Textbook Of Wood Technology State University Of New York, College Of Environmental Science and Forestry, United State Of America.

Sjostrom, E., 1995, Kimia Kayu, Dasar-dasar dan Penggunaan, Edisi Kedua, Gadjah Mada University Press, Yogyakarta.

Soenardi, 1976, Sifat-sifat Kimia Kayu. Yayasan Pembina Fakultas Kehutanan. Universitas Gadjah Mada, Yogyakarta. 